\title{
UPAYA PENINGKATAN KEGIATAN SOSIAL DAN INTERAKSI SESAMA MAKHLUK HIDUP PADA MASYARAKAT DAN HEWAN DI KELURAHAN SETIABUDI
}

\author{
Angel Carveling ${ }^{1)}$, Agustinus Sutanto ${ }^{21}$ \\ 1)Program Studi S1 Arsitektur, Fakultas Teknik, Universitas Tarumanagara, angelcarveling@gmail.com \\ 2)Program Studi S1 Arsitektur, Fakultas Teknik, Universitas Tarumanagara, berpikirteoripraksis@gmail.com
}

Masuk: 13-07-2020, revisi: 27-07-2020, diterima untuk diterbitkan: 24-09-2020

\begin{abstract}
Abstrak
Pada era globalisasi, kapitalisme terutama pada daerah perkotaan berkembang pesat. Populasi masyarakat didominasi oleh kaum milenial. Teknologi semakin berkembang membuat masyarakat terutama di perkotaan menjadi individualisme, egois dan mudah depresi. Hubungan antar manusia maupun dengan lingkungan semakin rusak. Salah satu hal yang dapat memperbaiki depresi manusia adalah dengan interaksinya bersama binatang. Interaksi yang terjadi antara manusia dan hewan dapat menghasilkan hormon endorfin yang membuat keduanya saling bahagia saat berinteraksi. Namun, hubungan manusia dan hewan semakin rusak. Hewan sering menjadi korban dari tingkah egois dan kebodohan manusia. Tingkat kepedulian manusia terhadap hewan semakin berkurang. Manusia dan hewan harus hidup berdampingan serta saling membantu untuk menjaga ekosistem dunia. Dengan metode arsitektur naratif, ruang berbagi "Ketika manusia bertemu dengann binatang peliharaan" di Kelurahan Setiabudi berusaha menuangkan berbagai program yang saling menguntungkan hubungan baik untuk manusia maupun binatang. Program dan desain pada ruang ketiga ini memperkuat narasi rumah hewan yang dapat dirasakan secara ruang dan visual oleh manusia dan bangunan manusia yang dapat dihuni dan memberikan keuntungan kepada hewan serta keduanya dapat saling hidup berdampingan di dalamnya. Sehingga desain bangunan ini berusaha untuk memberikan ruang ketiga pada Kelurahan Setiabudi agar manusia dapat berinteraksi dengan hewan untuk menghilangkan depresi dan hewan dapat hidup dengan damai di bangunan tersebut.
\end{abstract}

Kata kunci: Berdampingan; Hewan; Manusia; Ruang Ketiga

\begin{abstract}
In the era of globalization, capitalism, especially in urban areas is developing rapidly. The population is dominated by millennial. In the progression of the technology, people especially in urban areas become individualism, selfish and easily depressed. Relationships between humans and the environment are getting worst. One of the things that can rehabilitate human depression is interaction with animals. Interactions that occur between humans and animals can produce endorphins which make them happy when interacting. However, human and animal relations are increasingly damaged. Animals often be the victim from human selfishness and ignorance. The level of human concern for animals is diminishing. Humans and animals must coexist and help one another to protect the world's ecosystem. With narrative architectural methods, the sharing space "When Humans Meet Pets" in the Setiabudi Subdistrict is trying to set various programs that are mutually beneficial relations for both humans and animals. The program and design in the third space reinforces the narrative of the animal's house that can be felt visually by humans and human buildings that can be inhabited and provides benefits to animals and the two can co-exist together in it. So the design of this building is trying to provide a third space in the Setiabudi Subdistrict so that humans can interact with animals to reduce depression and animals can live peacefully in the building.
\end{abstract}

Keywords: Animals; Co-Exist; People; Third Place 


\section{PENDAHULUAN}

\section{Latar Belakang}

Di era globalisasi, kapitalisme sangat berkembang di banyak kota. Populasi yang di dominasi oleh kaum milenial dan perkembangan teknologi yang semakin pesat membuat masyarakat kota menjadi individualis. Dengan individualisme yang terjadi, masyarakat semakin egois dan memiliki daya saing antar manusia yang semakin ketat. Hubungan antar manusia mulai rusak dan muncul trust issue dalam kalangan masyarakat. Hal ini dapat menyebabkan trauma dan overthinking pada masyarakat untuk saling mempercayai satu sama lain terutama dalam menceritakan masalah dan beban pikiran. Akan muncul lingkungan yang buruk dengan masyarakat yang sulit bersosialisasi. Individu akan mengalami depresi karena beban pikiran permasalahan yang dihadapinya sehari-hari.

Manusia yang selalu bertambah jumlahnya membuat peningkatan kebutuhan hidup semakin bertambah. Seiring berjalannya waktu, kesenjangan makin terlihat masyarakat membuat banyak kaum yang mementingkan diri sendiri untuk memenuhi kebutuhan maupun memonopoli penjualan kebutuhan di pasar. Hal ini didukung oleh berkembangnya kapitalisme di berbagai kota. Sikap apatis mulai mendominasi manusia dan menjadikan manusia superior dari makhluk hidup lainnya. Konsep superior ini diperkuat oleh agama dan kebodohan manusia akan sumber yang ada di bumi. Hal-hal ini membuat makhluk hidup lain menjadi kaum tertindas dari tindakan manusia. Salah satu dari akibatnya adalah animal abuse untuk kepentingan manusia misalnya sirkus yang mempertunjukan binatang yang disiksa terlebih dahulu, kelinci yang digunakan sebagai binatang percobaan, dan pada hewan-hewan lainnya.

Manusia dan hewan bukan lagi sebuah hubungan yang saling menguntungkan. Namun, hubungan ini sudah merugikan salah satu pihak yaitu binatang. Mereka diperlakukan dengan tidak baik karena manusia dengan pemikirannya yang superior dari makhluk hidup lainnya. Namun, hal ini dapat diminimalisir dan sudah dilakukan oleh banyak manusia dari berbagai aspek. Hal tersebut misalnya dengan ada komunitas pencinta binatang, shelter untuk binatang, maupun gerakan atau organisasi yang anti memakan binatang.

Perkembangan kota Jakarta sebagai ibu kota negara membawakan kotanya dalam pertumbuhan infrastuktur yang semakin maju. Pembangunan infrastruktur terutama di kawasan-kawasan strategis sangatlah penting terjadi di Ibukota. Salah satu daerah yang berkembang menjadi daerah penting di ibu kota adalah Jakarta Selatan, termasuk kelurahan Setiabudi. Kelurahan ini termasuk dalam kawasan bisnis dan kawasan TOD sehingga dipadati dengan masyarakat yang sibuk dengan kegiatan perkantoran. Rutinitas ini dapat menyebabkan tingkat stres yang cukup tinggi bagi masyarakat yang beraktivitas di kawasan perkotaan. Banyak orang yang akan mencari hiburan untuk melepas kepenatan dari kesibukan rutinitas sehari-harinya. Namun, kawasan tersebut tidak mengakomodasi tempat untuk masyarakatnya melepas kejenuhan. Masyarakatnya harus keluar dari kawasan tersebut untuk mencari hiburan.

Kawasan Setiabudi dikelilingi oleh gedung-gedung perkantoran yang memerlukan banyak tenaga kerja sehingga timbul rumah kos untuk para karyawan perkantoran. Perbauran antara para kaum indekos, masyarakat baru dan masyarakat lamanya saling memberikan timbal balik. Hal ini dapat dilihat dari munculnya tempat makan dan laundry pakaian yang mengakomodasi kebutuhan masyarakatnya. Para kaum komuter juga menjadi bagian sehari-hari dari kawasan tersebut yang memberikan banyak peluang untuk masyarakatnya dalam membuka usaha untuk mengakomodasi kebutuhannya. Komposisi masyarakat baru membentuk sebuah karakter daerah masyarakat perkotaan yang individualis.

Sebuah third place yang akan menjadi tempat interaksi antara manusia dan binatang agar dapat saling membantu dibutuhkan pada kawasan ini. Salah satu yang dibutuhkan pada 
kawasan ini adalah reaksi yang dihasilkan dari interaksi manusia dan binatang. Masyarakat kota terutama di kelurahan Setiabudi yang mempunyai beban pikiran dapat bermain dan bercerita kepada binatang yang ditampung dan dirawat oleh third place ini. Salah satu film yang menampilkan mengenai cerita masyarakat perkotaan yang memiliki binatang peliharaan adalah pada film "The Secret Life Of Pets". Narasi dari film tersebut dan tipologi dari rumah binatang akan menjadi metode yang diterapkan dalam desain third place tersebut.

\section{Rumusan Permasalahan}

Permasalahan yang diangkat dari isu kemudian disesuaikan dengan kawasan yang menghadapi permasalahan yang sama. Sehingga terdapat beberapa rumusan dari permasalahan yaitu : 1 . Bagaimana peran arsitektur dalam mewadahi kegiatan sosial dan interaksi antara manusia dan hewan di sebuah kehidupan perkotaan pada Kelurahan Setiabudi, 2. Bagaimana penerapan metode narasi dapat menceritakan kehidupan binatang dan manusia dalam spasialitas dan desain bangunan.

\section{Tujuan}

Terdapat manfaat dari perancangan proyek dalam kontribusinya untuk kelurahan Setiabudi dan masyarakat yang beraktivitas pada kawasan tersebut maupun pendatang yang berkunjung ke kawasan tersebut. Tujuan yang hendak dicapai oleh perancangan ini adalah 1 . Menjadi tempat ketiga untuk masyarakat sekitar dapat saling bertemu, mengenal dan menjadi bermain bersama dengan binatang, 2. Agar dapat menjadi tempat yang akan dikunjungi saat masyarakat membutuhkan wadah untuk mengurangi beban pikiran, dan 3. Mewadahi interaksi saling membantu antara manusia dan binatang.

\section{KAJIAN LITERATUR}

Dalam memahami third place, mengkaji teori-teori yang sudah ada dilakukan untuk mendapatkan ilmu mengenai tema tersebut. Melakukan kajian terhadap teori menjadi salah satu dari kegiatan yang harus dilakukan dalam merancang third place dengan membaca dari sumber-sumber yang sudah tersedia, dan memahami tema sehingga dapat mendefinisikan jenis bangunan yang hendak dibuat. Teori third place dari berbagai ahli seperti Ray Oldenburg, Herman Hertzberger dan lainnya akan dibahas pada subab ini.

\section{Third Places}

"Oldenburg calls one's "first place" the home and those that one lives with. The "second place" is the workplace - where people may actually spend most of their time. Third places, then, are "anchors" of community life and facilitate and foster broader, more creative interaction." (Oldenburg, 1991)

Menurut Oldenburg, third place merupakan tempat dimana orang dapat bersantai di area publik, bertemu dengan orang-orang yang tidak asing dan mendapat teman baru. Dikatakan bahwa third place merupakan sebuah tempat dimana manusia menghabiskan waktu diantara kesibukan pekerjaan dan kenyamanan rumah. Hal ini membuat tempat ketiga mempunyai peran penting dalam kehidupan sebuah masyarakat. Dengan adanya tempat ketiga, manusia sebagai makhluk sosial akan lebih mempunyai wadah untuk bersosialisasi. Menurut Oldenburg, tempat ketiga memiliki karakter, yaitu:

a. Neutral ground. Pelaku di tempat ketiga memiliki sedikit atau tidak ada kewajiban untuk berada di sana. Mereka tidak terikat ke daerah finansial, politik, hukum, atau sebaliknya dan bebas untuk datang dan pergi.

b. Leveler (a leveling place). Tempat ketiga tidak mementingkan status individu dalam suatu masyarakat. Status ekonomi atau sosial seseorang tidak penting di tempat ketiga, hal ini menimbulkan rasa kesamaan di antara para pengunjungnya. Tidak ada persyaratan yang akan mencegah kehadiran mereka di tempat ketiga. 
c. Conversation is the main activity. Percakapan menyenangkan dan bahagia adalah fokus utama dari aktivitas di tempat ketiga, meskipun tidak harus menjadi satu-satunya aktivitas. Nada berbicara di tempat ketiga biasanya ringan dan banyak berkomunikasi tentang hal lucu, suasana menyenangkan terbentuk pada tempat ketiga.

d. Accessibility and accommodation. Tempat ketiga harus terbuka dan mudah diakses oleh mereka yang menempatinya. Tempat tersebut juga harus akomodatif, artinya mereka memenuhi kebutuhan pengunjungnya, dan semua pengunjung merasa kebutuhan mereka telah terpenuhi.

e. The regulars. Tempat ketiga memiliki sejumlah pengunjung tetap yang membentuk karakter daerah, dan membantu mengatur suasana. Tempat ketiga juga menarik pendatang baru, dan membantu seseorang yang baru ke tempat tersebut merasa diterima dan terakomodasi.

f. A low profile. Tempat ketiga secara karakteristik menerima segala jenis kelas masyarakat. Tempat ketiga memiliki perasaan yang sederhana. Tempat ketiga tidak pernah sombong, dan menerima semua jenis individu dari berbagai lapisan masyarakat.

g. The mood is playful. Nada percakapan di tempat ketiga tidak pernah muncul dengan ketegangan atau permusuhan. Sebaliknya, tempat ketiga memiliki sifat yang menyenangkan, di mana percakapan cerdas dan olok-olok sembrono merupakan hal yang biasa.

h. A home away from home. Pengunjung tempat ketiga akan sering memiliki perasaan hangat, dan kepemilikan yang sama seperti di rumah mereka sendiri. Mereka merasa sepotong diri mereka berakar di sana, dan mendapatkan regenerasi spiritual dengan menghabiskan waktu di sana.

Para urban planner mencari cara untuk menyatukan sebuah lingkungan dengan fokus pada peran "third place" yang dapat memperkuat perasaan orang terhadap lingkungannya. Third place merupakan tempat dimana seseorang menghabiskan waktu antara rumah (sebagai first place) dan tempar kerja (sebagai second place). Tempat tersebut menjadi tempat untuk bertukar pikiran, menikmati waktu dan membangun komunikasi dengan orang lainnya.

Third place merupakan hal yang penting dalam membentuk sebuah komunitas pada sebuah lingkungan. Berdasarkan lokasinya, status sosial dan latar belakang dapat teratakan dengan cara yang jarang terjadi akhir-akhir ini, dengan membuat orang merasa mereka diperlakukan sama. Pembicaraan sehari-hari yang tidak formal menjadi aktivitas utama dan fungsi paling penting. Third place merujuk sebagai "ruang tamu" dalam masyarakat.

Kebanyakan tata rencana kota berusaha menyegarkan kembali lingkungan metropolitan dengan melibatkan third place terutama ruang publik, untuk mencoba dan mematahkan status sosial. Salah satu contohnya adalah wilayah The Greater Washington D.C., dalam sebuah eksperimen di salah satu taman di Washington D.C para pekerja kantor dapat memesan kursi dan meja untuk bertemu dan bersosialisasi. Di sekitar Silver Spring, Maryland, The Outbox adalah sebuah eksperimen outdoor dan wall-less vestibule dengan kursi dan Wi-Fi yang tersedia untuk digunakan oleh orang-orang.

Para lansia beresiko tinggi terputus secara sosial, dan itu menarik perhatian para inovator third place. Misalnya, Leading Age Maryland, sebuah organisasi penelitian dan advokasi, bekerja sama dengan lembaga kesehatan dan arsitek untuk merancang perumahan senior di area "ruang bersama", yang terletak di dekat transportasi, perumahan non-tua, dan mitra masyarakat lainnya seperti universitas dan fasilitas medis. Upaya-upaya ini mencakup fasilitas bergaya kafe yang ditargetkan untuk manula, tetapi itu juga menarik bagi masyarakat luas. Ini sangat kontras dengan pola umum menciptakan ruang-ruang lansia yang terpisah sendiri, dengan layanan rumit tetapi sedikit kontak dengan komunitas luar. 
Tapi banyak tempat ketiga yang hilang karena semakin banyak orang Amerika yang menjadi menggunakan hal digital untuk koneksi sosial. Meningkatnya harga real estate di banyak kota juga membuat pusat pertemuan informal berbiaya rendah lebih sulit dipertahankan. Ini bukan hanya masalah kota pusat. Lingkungan pinggiran kota sering mengabaikan pentingnya third place.

Oldenburg (1991) menyalahkan "zonasi yang tidak berfungsi" yang melarang perusahaan komersial di daerah perumahan, yang menyebabkan orang-orang Amerika di pinggiran kota harus menggunakan mobil mereka untuk semua yang mereka butuhkan, dan mal-mal serta toko-toko memadati bisnis kecil dan tempat hang out. Penelitian oleh rekan-rekan Brookings.edu, Alan Berube dan Elizabeth Kneebone menemukan bahwa sekarang orangorang mengalami tingkat kemiskinan yang lebih tinggi di beberapa pinggiran kota daripada di kota-kota. Jaringan yang lebih kuat dari tempat ketiga di kota dan pinggiran kota dapat membantu membangun koneksi sosial dan ekonomi yang diperlukan untuk keluar dari kemiskinan.

Kota dan pinggiran kota dapat mengambil langkah-langkah untuk menciptakan kondisi yang lebih ramah bagi tempat ketiga untuk berkembang dan berkembang. Salah satu langkah penting adalah memastikan zonasi mengakomodasi fungsi-fungsi penggunaan campuran di area perumahan lainnya. Rute bus dan titik pemberhentian yang nyaman juga bisa menjadi sangat penting untuk keberlangsungan tempat ketiga. Wi-Fi gratis, yang disediakan oleh lingkungan kota, dapat mengubah banyak tempat menjadi titik pertemuan dan menyatukan orang-orang dari berbagai usia. Penguatan tempat-tempat umum dan menjelajahi arsitektur baru dan penggunaan ruang juga penting. Perubahan desain kecil dapat mendorong interaksi antar kelompok yang mungkin terputus satu sama lain. Sebagai contoh, Gallaudet University, Washington, DC University untuk tuna rungu dan tuna rungu, telah meluncurkan inisiatif "Deaf Space" dan telah bekerja dengan arsitek, mahasiswa, dan anggota masyarakat untuk merancang ruang di dalam kampus Gallaudet dan lingkungan sekitarnya yang lebih akomodatif dan inklusif bagi mereka yang mengalami gangguan pendengaran.

Penggunaan yang lebih kreatif juga dapat dibuat dari undang-undang dan peraturan yang ada untuk mendorong upaya tersebut. Misalnya, ketentuan Undang-Undang Perawatan Terjangkau mensyaratkan rumah sakit nirlaba, sebagai syarat status bebas pajak mereka, untuk menganalisis kebutuhan kesehatan setempat di komunitas mereka dan membantu mengatasinya dengan menggunakan sumber daya rumah sakit. Mengingat apa yang kita ketahui tentang pentingnya interaksi sosial dan jaringan komunitas untuk mengatasi masalah kesehatan mental tertentu, rumah sakit dapat mengidentifikasi tempat ketiga yang ada atau mungkin untuk membantu memperluas ketersediaan tempat pertemuan, ruang berjalan dan akses Wi-Fi publik. Rumah sakit memiliki posisi yang baik untuk bekerja dengan bisnis lokal, universitas, pusat senior, dan lembaga pemerintah setempat.

Third Place merupakan tempat dimana seseorang menghabiskan waktu antara home dan workplace, tempat yang menerima setiap individu tanpa melihat latar belakangnya, dan pengunjungnya dapat bertukar pikiran, serta membangun relasi. Third place diperlukan bagi semua orang karena tempat tersebut dapat digunakan untuk melepaskan pemikiran berlebih, dan menghibur mereka akan kepenatan dalam melakukan aktivitas sehari-hari.

\section{Merancang Third Places}

Henri Lefebvre (1991) mendedikasikan banyak tulisan filosofisnya untuk memahami pentingnya produksi ruang untuk menghasilkan sebuah produk dari hubungan sosial. Argumennya menyiratkan perpindahan perspektif dari ruang ke proses produksinya. Hal ini merangkul banyaknya ruang yang diproduksi secara sosial dan dibuat produktif dalam praktik sosial, serta fokus pada karakter yang kontradiktif, konflik, dan politik dari proses produksi 
ruang. Sebagai seorang teoretikus Marxis (tetapi sangat kritis terhadap strukturalisme ekonomi yang mendominasi wacana akademis di zamannya), Lefebvre berpendapat bahwa produksi ruang sosial dalam kota penting bagi masyarakatnya, termasuk untuk sebuah kapitalisme. Ruang sosial sebagai lived space dalam masyarakat berpengaruh terhadap spasial yang direncanakan (conceived) dan representasi ruang yang terinterpretasi (perceived) (Lefebvre, 1991)

Menurut Richard (2007), place making dalam sebuah kota untuk para creative class menjadi tren untuk arsitektur landscape. Place menjadi sebuah unit pengatur pusat ekonomi dan masyarakat kita, mengambil peran yang dulu dimainkan oleh perusahaan besar. Dalam menarik, mempertahankan, dan mendapatkan yang terbaik dari para talenta yang luar biasa, organisasi perlu menawarkan tempat yang mengagumkan untuk bekerja. Seperti yang terjadi pada perusahaan google, facebook dan lainnya dalam mengakomodasi sebuah tempat kerja yang menarik dan kreatif.

"The most active third place were observed to have a permeable relationship between the public realm and the private establishment, top, fostering activity and interaction." (Richard, 2007)

Dalam membuat tempat ketiga terdapat aspek yang penting yaitu permeable. Permeable ini akan menimbulkan pergerakan manusia dari sebuah tempat pribadi menuju ke public realm. Maka, third place diharapkan menjadi sebuah rembesan masyarakat dari rumahnya menuju tempat kerjanya dan terjadi juga pada sebaliknya.

Dalam menjadi sebuah permeable bagi masyarakat dalam sebuah kawasan, berarti third place ini menjadi sebuah perantara antara home dan workplace dari masyarakatnya. Areanya berada dalam antara atau disebuah garis ambang antara dua tempat dengan dua suasana yang berbeda. Hertzberger menjelaskan bahwa sebuah garis ambang (in between) merupakan transisi dari dua territorial yang berbeda namun suasana dari dua territorial tersebut dapat mempengaruhi sebuah area transisi atau area pada ambang batas tersebut (Hertzberger, 1991).

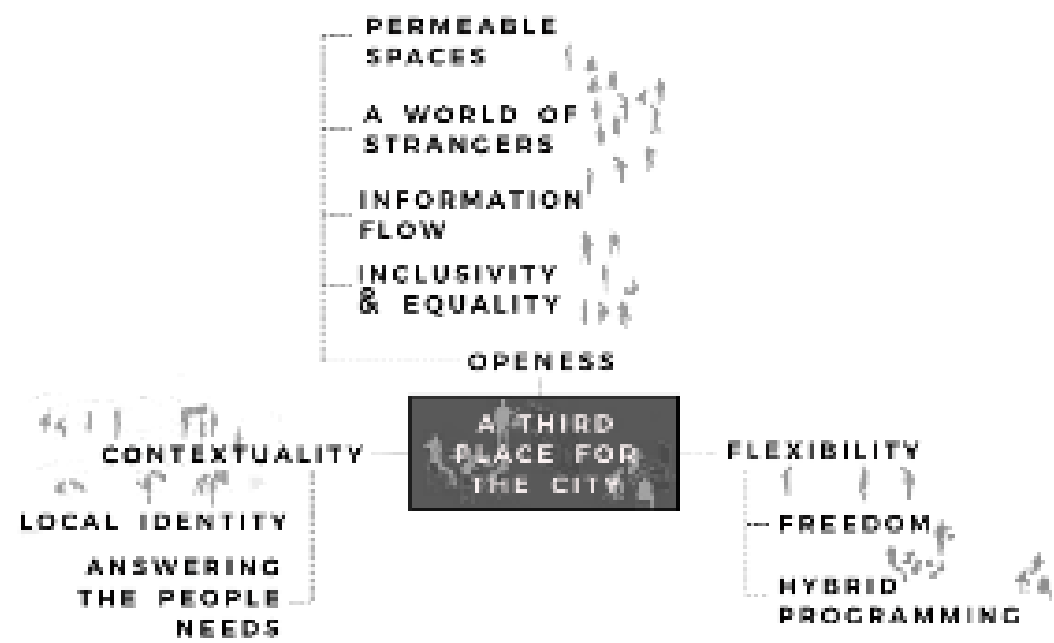

Gambar 1. Hubungan antar Fungsi dan Kebutuhan Untuk Merancang "Third Place" Sumber : Penulis, 2020.

Sebuah garis ambang (in between) memberikan kunci untuk transisi dan hubungan antara daerah-daerah dengan klaim teritorial yang lain, dan sebagai tempat dalam territorial haknya sendiri, itu merupakan, kondisi spasial untuk pertemuan dan dialog antara bidang-bidang yang berbeda. Nilai konsep ini paling eksplisit di ambang 'par excellence', pintu masuk ke rumah. 
Merealisasikan sebuah garis ambang ini sebagai sebuah in between berarti pertama, menciptakan pengaturan untuk menyambut dan sekaligus juga perpisahan, dan karena itu terjemahan ke dalam istilah arsitektur yaitu area untuk sebuah hospitality. selain itu, ambang tersebut sebagai fasilitas yang dibangun juga sama penting dalam sebuah kontak sosial seperti untuk dinding tebal pribadi. Kondisi untuk privasi dan kondisi untuk pemeliharaan kontak sosial dengan orang lain sama pentingnya. Pintu masuk, beranda, dan banyak bentuk lain di antar ruang memberikan peluang untuk 'akomodasi' antara dunia lain yang berdampingan.

\section{Smart Cities: A Spatialized Intelligence}

Smart cities menggunakan teknologi informasi dan komunikasi dalam upaya untuk pembangunan ekonomi yang berkelanjutan dan mendorong bentuk-bentuk baru kehidupan kolektif. Ini menjadikan smart city sebagai fokus penting untuk para insinyur, arsitek, perancang kota, perencana kota, dan politisi, dalam masalah budaya dan mengambil sikap yang kritis dan menguraikan konsekuensinya pada ruang dan pengalaman perkotaan. Lensa budaya dan kritis ini jauh lebih penting karena smart city adalah cita-cita yang mendalam pada keyakinan kota utopia sebagai gejolak transformasi perkotaan. Cita-cita ini memiliki karakter mandiri yang kuat. Kota-kota ini akan menjadi 'cerdas' karena kami menginginkannya (Picon, 2015)

Menurut Picon (2015) dalam bukunya, terdapat wacana dimana saat dibangunnya kota, terdapat perancangan yang diterapkan dari chip dan sensor yang memungkinkan untuk memantau apa yang terjadi dalam infrastruktur hingga smartphone yang menghubungkan individu. Kota menjadi sesuatu yang teraktivasi. Aktivasi ini menghasilkan dua visi yang berbeda: di satu sisi, ambisi neo-cybernetic untuk mengarahkan kota dengan cara yang paling efisien, dan di sisi lain, pendekatan partisipatif yang lebih bottom-up, dimana terdapat individu yang dapat menemukan cara kerja sama baru. Analisis menyeluruh dari kedua tren ini mengungkapkan bahwa keduanya saling melengkapi. Smart city dalam waktu dekat akan dihasilkan dari penyesuaian dua visi tersebut. Dalam proses ini, ruang kota memainkan peran yang menentukan. Kontemporer smart city dengan pergantian spasial digital. Berdasarkan perkembangan teknologi utama seperti geo-lokalisasi dan augmented reality, meningkatknya kepentingan ruang untuk menjelaskan peran strategis pemetaan dalam evolusi pengalaman perkotaan. Sepanjang penelusuran beberapa faktor perancangan utama, buku ini terus bergerak dari teknologi ke tata ruang dan juga dari penilaian kritis atas eksperimen yang ada hingga spekulasi tentang munculnya bentuk baru kecerdasan kolektif. Di masa depan, kotakota akan menjadi lebih pintar dengan cara yang jauh lebih literal daripada yang sering diasumsikan saat ini.

Terlepas dari tantangan yang diuraikan, kebangkitan smart cities merupakan revolusi sejati, sebanding dengan kelahiran kota-kota industri besar di abad ke-19 dan kemunculan kota berjejaring sebagai cita-cita perkotaan dan proses fisik transformasi kota. Sementara dampak revolusi ini pada bentuk perkotaan masih diselimuti ketidakpastian, pengaruhnya pada struktur temporal pengalaman kota sudah dapat diamati. Kita hidup di kota-kota yang bergerak ke ritme peristiwa yang semakin banyak yang dapat diikuti secara nyata.

\section{Manusia dan Binatang}

Di era modern ini, manusia memiliki kedekatan dengan binatang dan berusaha mempertahankan kedekatan tersebut. Ikatan antara manusia dan binatang merupakan sebuah hubungan mutualisme dan hubungan dinamis antara keduanya terpengaruh oleh kebiasaan untuk kesejahteraan dan kesehatan dari keduanya. Hubungan manusia dan binatang terjadi dalam bentuk tertentu yang unik. Binatang peliharaan tidak diperlukan untuk bekerja dan manusia hanya menikmati mempunyai mereka di rumahnya. Persahabatan antara keduanya 
membuat si binatang tidak memiliki fungsi tertentu dan tidak dapat dimengerti apa yang diharapkan manusia dari binatang-binatang ini.

Di sisi binatang, mereka dapat mengembangkan kemampuan untuk memahami dan menafsirkan sinyal manusia. Setiap interaksi adalah sumber memori baik positif atau negatif dan hubungan yang dihasilkan dari suksesnya interaksi akan tergantung pada frekuensi memori tersebut. Lingkungan manusia bukan hal yang biasa untuk binatang. Kebiasaan binatang merupakan sebuah studi scientific dari the wild and cara luar biasa dimana binatang dapat berinteraksi dengan lainnya.

Animal shelter adalah sebuah tempat dimana binatang tersesat, hilang, ditinggalkan ataupun menyerah, kebanyakan anjing dan kucing dan terkadang binatang liar yang sakit juga dijaga dan direhabilitasi.

\section{Animal Therapy}

Animal Therapy adalah sebuah interaksi yang terarah antara seseorang dan binatang yang sudah dilatih, biasanya juga melibatkan pelatih binatang tersebut. Terapi binatang ini disosialisasikan dan dilatih untuk meningkatkan keamanan dan memberi kasih sayang kepada orang dalam berbagai keadaan lingkungan yang stres. Biasanya hal ini dapat dilihat di rumah sakit, sekolah dan area bencana, serta diklasifikasikan menjadi tiga macam yaitu: Therapeutic Visitation Animals, Animal Assited Therapy Animal dan Facility Therapy Animals. Animal therapy kemudian dibagi menjadi 2 tipe, yaitu :

a. Animal-Assited Activities (AAA), yang dimana memberikan kesempatan untuk meningkatkan kualitas hidup. AAA dikirimkan dalam berbagai keadaan lingkungan oleh pelatih profesional special, paraprofesional, dan sukarelawan, dalam asosiasi dengan binatang yang terdapat kriteria spesifik. AAA biasanya berupa aktivitas "meet and greet" yang melibatkan binatang untuk mengunjungi orang-orang. Aktivitas yang sama dapat diulang kepada banyak orang, tidak seperti terapi yang disesuaikan dengan orang atau kondisi tertentu.

b. Animal-Assited Therapy (AAT), yang dimana mempunyai tujuan terarah agar binatang terlibat kriteria spesifik tertentu dalam sebuah proses pengobatan. AAT diarahkan dan dikirim oleh pelayanan manusia yang profesional dengan keahlian special dan pelatihan dari profesional. AAT didesain untuk mempromosikan peningkatan dalam fisik manusia, emosional dan kemampuan berpikir serta kemampuan intelektual. AAT dikembangkan dalam berbagai keadaan, dapat untuk individu maupun grup. Aktivitas ini biasanya didokumentasikan dan dievaluasi.

Adapun manfaat dari aktivitas animal therapy untuk manusia. Terdapat ikatan kuat antara manusia dan binatang. Binatang dapat menerima, tidak mengancam dan tidak menghakimi, membuat hal itu memudahan manusia untuk terbuka. Beberapa manfaatnya, yaitu :

a. Meningkatkan keterampilan motorik,

b. Meningkatkan fokus dan perhatian,

c. Meningkatkan kepercayaan diri dan kemampuan untuk peduli pada diri sendiri,

d. Mengurangi kecemasan, kesedihan dan isolasi diri,

e. Mengurangi tekanan darah, depresi dan resiko penyakit jantung atau stroke,

f. Meningkatkan kepercayaan, empati dan kemampuan bekerja bersama,

g. Memperbaiki pengendalian diri,

h. Meningkatkan keterampilan untuk menghadapi masalah,

i. Mengurangi ketergantungan pada obat, dan

Animal-Assited Therapy terkadang digunakan untuk mengobati social anxiety disorder (SAD). Binatang secara unik cocok untuk membantu individu dengan $S A D$, dengan mereka yang tidak menghakimi dalam memberikan dukungan dan mempunyai kesempatan untuk belajar 
berinteraksi dengan lainnya. Binatang digunakan dalam terapi bisa berbagai jenisnya. Anjing dan kuda merupakan salah satu dari banyak yang dipikirkan oleh orang-orang jika mendengar aktivitas ini, tetapi binatang eksotis lainnya dapat melakukan proses terapi ini.

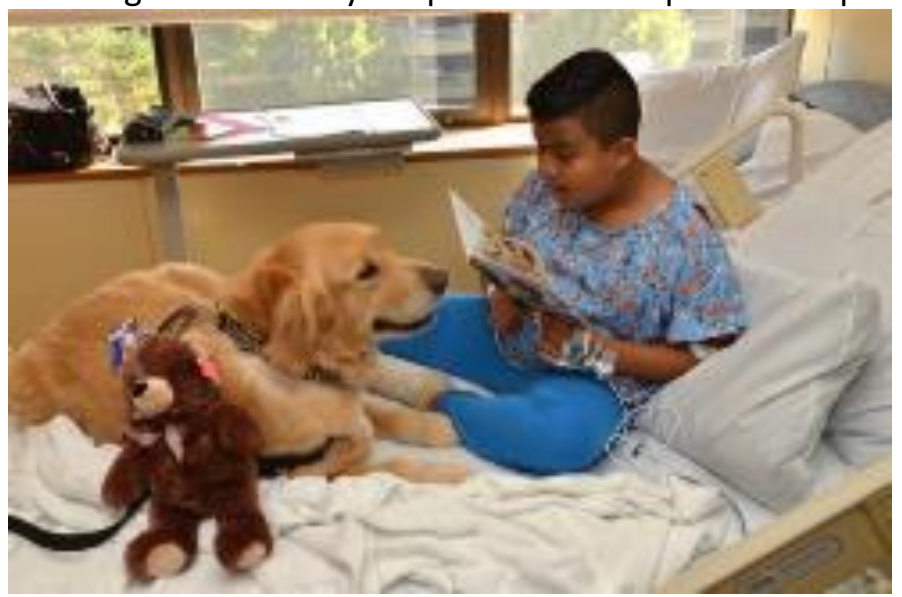

Gambar 2. Animal-Assited Therapy

Sumber: huffpost.com

\section{METODE}

Metode yang digunakan untuk mengumpulkan data adalah melakukan riset terhadap kawasan untuk mencari isu terkait serta menghubungkannya dengan kebutuhan kepada kontribusi lingkungan. Kemudian, dilakukan perancangan desain dengan menggunakan metode narrative architecture yang berasal dari Bernard Tschumi (1994) dalam bukunya The Manhattan Transcripts.

Buku tersebut menjelaskan bahwa dilakukannya transkrip terhadap sebuah cerita yang bertujuan untuk membuat interpretasi secara arsitektur dari sebuah kenyataan. Dimana digunakan sebagian struktur dari indikasi berupa foto maupun bukti kejadian (biasa dikenal dengan sebutan fungsi maupun program). Pada saat yang sama, denah, potongan, dan diagram mengindikasi pergerakan dari berbagai peran membentuk sebuah set panggung arsitektural. Transkrip ini menghubungkan secara kompleks antara space dan use, set dan script, tipe dan program, serta object dan events. Sehingga narasi ini memiliki definisi bahwa arsitektur memiliki event, movement dan space yang dapat membentuk sebuah stage set (Tshcumi, 1994).

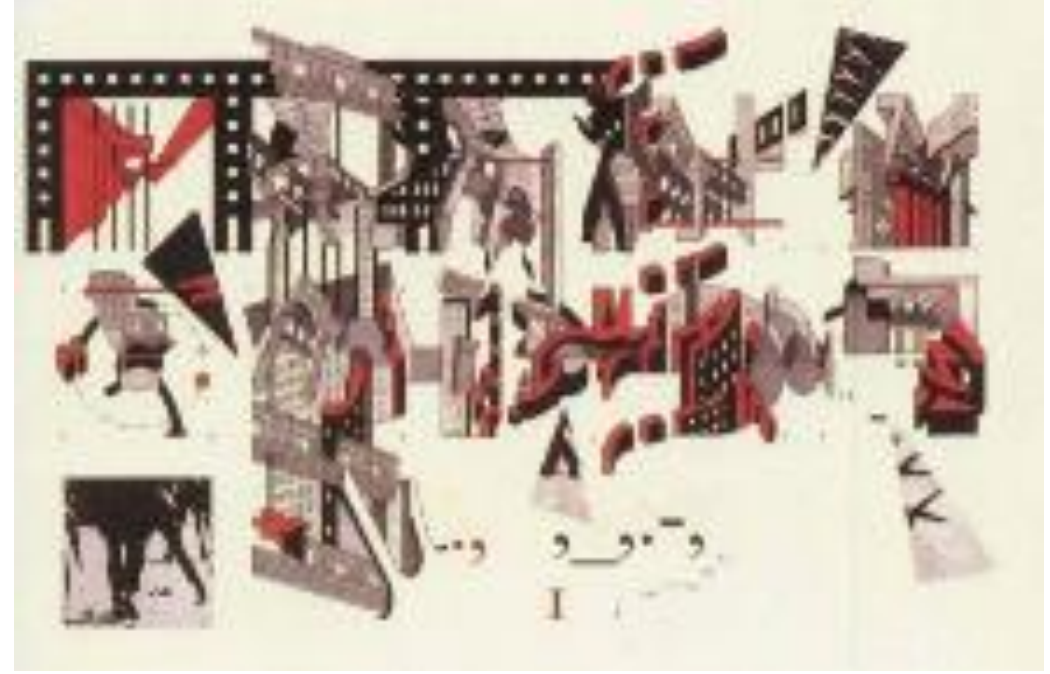

Gambar 3. Program Aktivitas Bangunan

Sumber: Penulis, 2020 


\section{DISKUSI DAN HASIL}

\section{Analisis Kawasan}

Kelurahan Setiabudi berada di kecamatan Setiabudi, Jakarta selatan. Terletak di kawasan segitiga emas Jakarta yang merupakan area bisnis dan komersial di Jakarta. Setiabudi sendiri berasal dari nama pahlawan Indonesia, Ernest Douwes Dekker, yang dikenal juga dengan Danudirdja Setiabudi. Dikelilingi oleh banyak moda transportasi, mulai dari KRL hingga MRT. Berdasarkan pengamatan secara langsung ke kawasan, zona tengah pada kawasan tersebut didominasi oleh perumahan dan dikelilingi oleh kawasan perkantoran, perdagangan dan jasa. Perumahannya didominasi oleh rumah-rumah berupa indekos.

Tapak berada di Jl. Setiabudi Tengah dengan lebar 8 meter, dan Jl. Setiabudi VI Gg.9 lebar 4 meter. Kondisinya adalah lahan kosong dengan rencana penggunaan lahan sebagai zona campuran yang masih berupa rawa-rawa bersebelahan dengan danau yang pada rencana pengunaan lahan akan menjadi zona perkantoran, perdagangan dan jasa yang dibatasi oleh jalanan dengan lebar $20 \mathrm{~m}$. Tapak ini dipilih karena berada di sekitar zona perumahan dan komersial yang dapat mengakomodasi third place masyarakat untuk menghabiskan waktu antara home pada zona perumahannya dan workplace pada zona komersialnya. Dengan pengunjung dari perumahan dan area kerja dengan radius $0-850 \mathrm{~m}$ dari tapak serta banyaknya moda transportasi yang walkable ke tapak membuat third place ini akan mendapat pengunjung tetap yang mudah diakses untuk semua warga Kelurahan Setiabudi serta dapat menarik strangers.

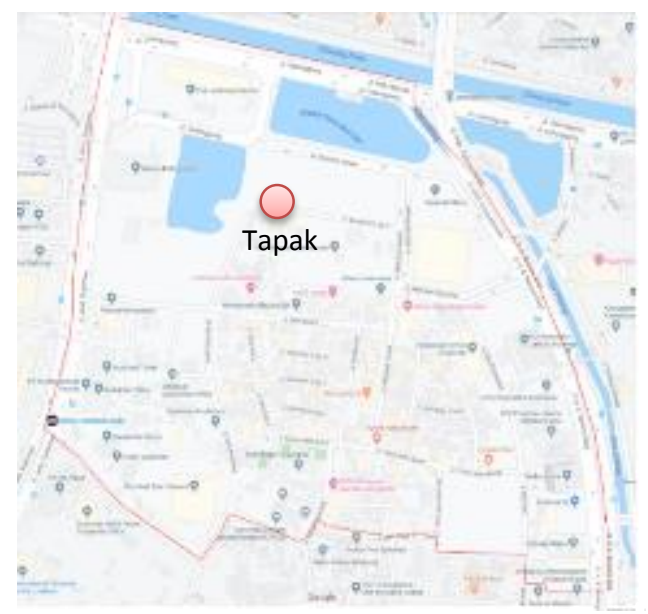

Gambar 4. Peta Kelurahan Setiabudi

Sumber: Google maps yang Diolah Penulis, 2020.

Berdasarkan wawancara secara acak pada jam pulang kerja dengan beberapa pekerja kantoran, mereka berpendapat bahwa tempat tersebut membutuhkan sebuah tempat untuk mencari makan yang murah dan tempat untuk berbelanja sembari menghabiskan waktu istirahat ataupun waktu menunggu redanya keramaian pada transportasi umum maupun jalanan. Selain itu, hasil wawancara juga menunjukkan dibutuhkan sebuah tempat untuk hiburan yang tidak biasa dan terjangkau untuk berbagai kalangan.

\section{Usulan Aktivitas dan Program}

Berdasarkan isu yang diangkat dan narasi lingkungan yang diimplementasikan juga dalam skema usulan aktivitas dan program, sehingga berikut adalah program-program yang ada pada bangunan. Bird, dog, cat zone sebagai penyelesaian masalah untuk isu beserta desain ruangnya. Meet, work, eat dan socialize sebagai narasi kebutuhan sehari-hari lingkungan Kelurahan Setiabudi dalam membuat sebuah tempat ketiga yang akan mengakomodasi penduduk sekitar tanpa melupakan kontribusi terhadap lingkungan. 


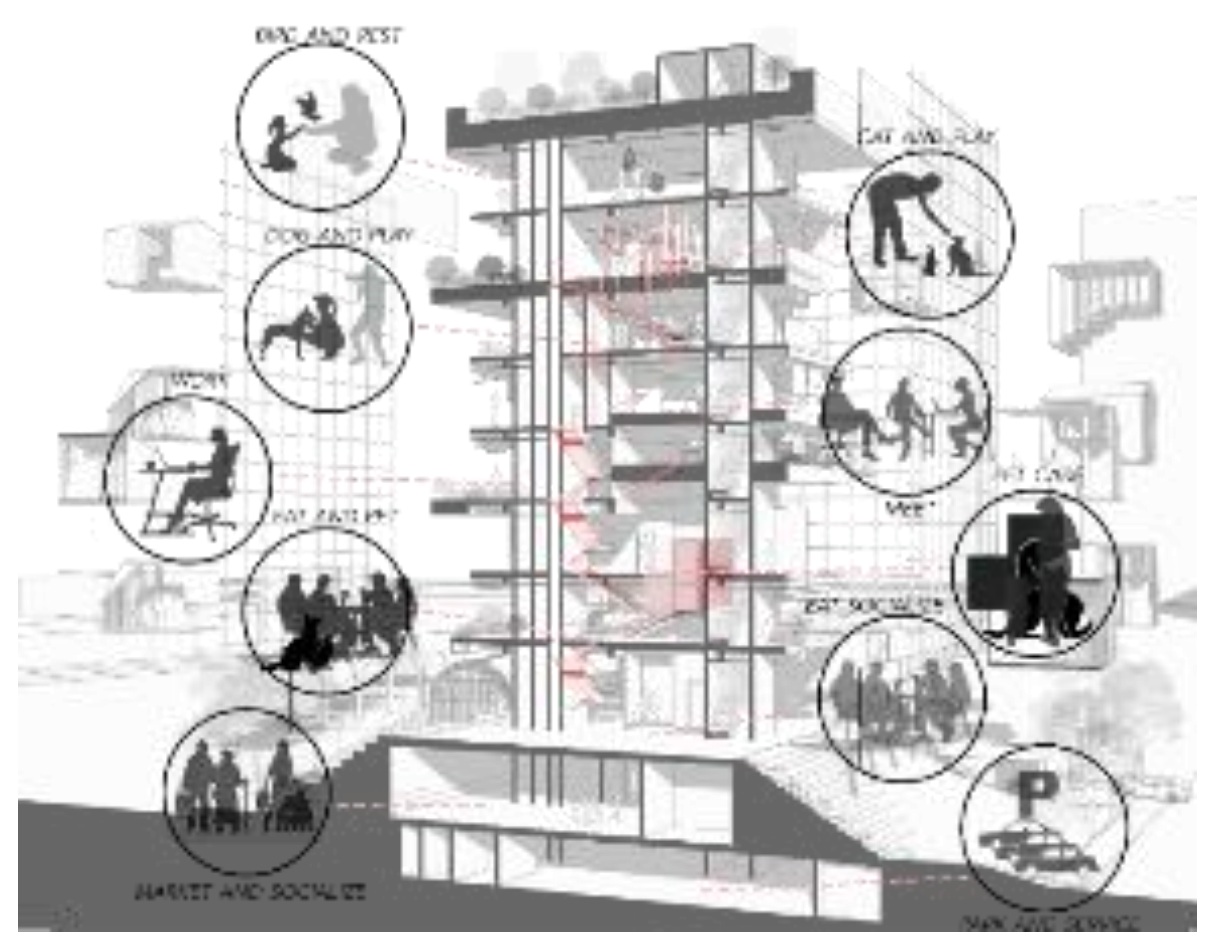

Gambar 5. Program Aktivitas Bangunan

Sumber : Penulis, 2020

\section{Konsep Perancangan}

Konsep dari perancangan ini adalah menggunakan metode narasi sebagai dasar ide dari desain. Metode narasi ini di ekstraksi dari film yang berjudul "the secret life of pets". Dimana pada film tersebut, terdapat narasi yang mirip dengan Kelurahan Setiabudi mengenai perkotaan dan manusianya. Namun pada film tersebut, ada sesuatu yang berbeda yang membuat kota tersebut tetap berwarna yaitu sosialisasi dan hal yang dapat menyebabkan hal itu terjadi. Dengan hal tersebut, maka dalam merancang, film tersebut menjadi acuan untuk narasi stage set dalam alur desain ini.

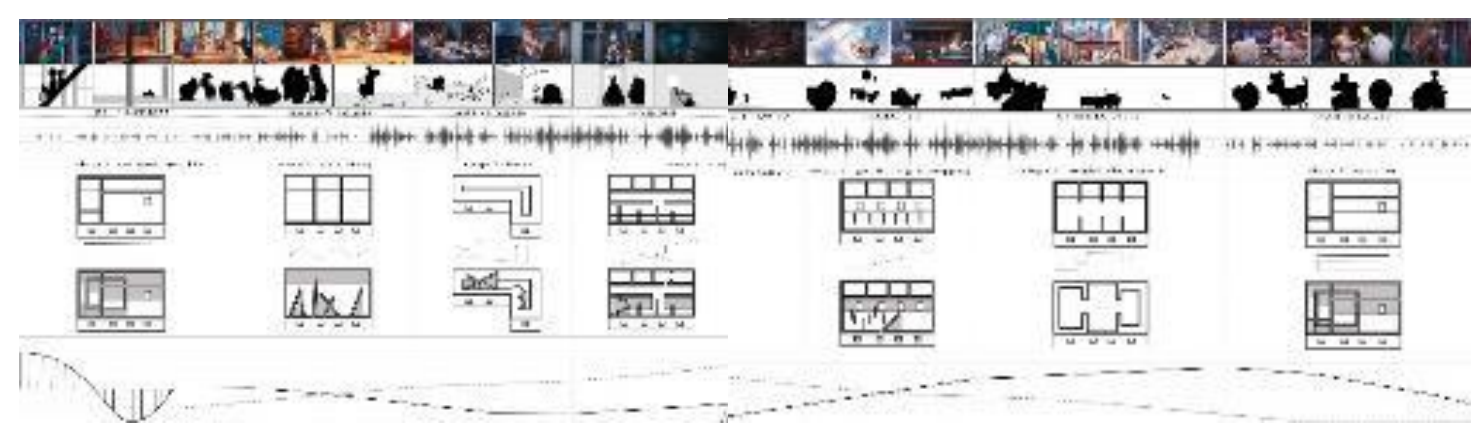

Gambar 6 Stage Set dari Metode

Sumber : Penulis, 2020

Selain metode narasi yang menjadi alur bangunan, tipologi rumah binatang dalam membuat suasana bangunan kental dengan nuansa kehewanan dianalisis menjadi salah satu bentuk yang membentuk fasad bangunan. Berbagai rumah binatang peliharaan dianalisis menjadi 4 jenis tipe untuk dirasakan oleh manusia dalam lingkungan perkotaan yang sibuk. Sehingga desain ini akan menjadi kontras dengan bangunan di perkotaan manusia yang sibuk. 


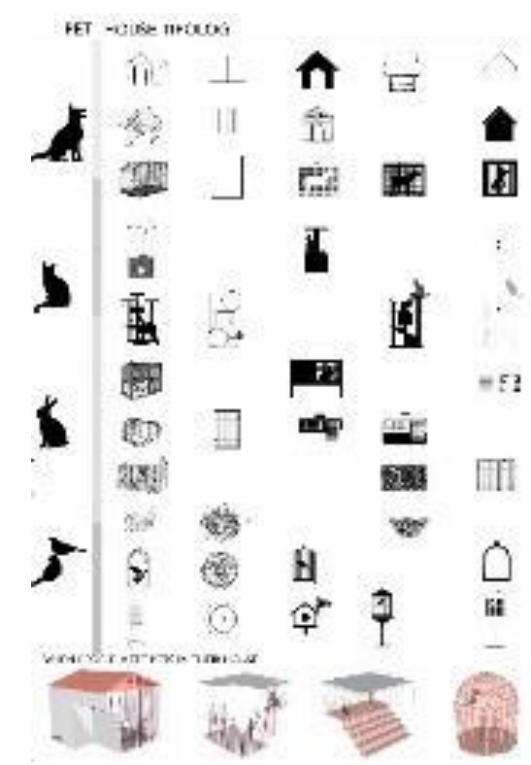

Gambar 7. Tipologi Rumah Binatang Sumber: Penulis, 2020

\section{Skema Desain}

Desain dimulai dengan memperhatikan peraturan lingkungan sekitar, seperti urban fabric yang ada, ketinggian bangunan yang diperbolehkan, KDB, KLB, KDH yang mempengaruhi massa bangunan dan juga kebutuhannya terhadap kontribusi lingkungan sebagai narasi dari luar. Setelah itu terbentuklah massing utama yang kemudian akan dikombinasikan dengan konsep perancangan sebagai narasi dari dalam kepada desain perancangan bangunan. Pada proses selanjutnya, struktur dan material dikomposisikan masuk ke dalam desain sehingga terbentuk bangunan. Interior dan rangka void membentuk fasad utama bangunan, sehingga transparansi bangunan sangat dirasakan. Bangunan menunjukkan keterbukaannya terhadap alam dan sekitar dengan terbukanya ruang-ruang maupun pintu masuk kedalamnya. Kemudian, program bangunan dimasukan ke dalam bangunan membentuk hasil akhir zona dan desain bangunan.

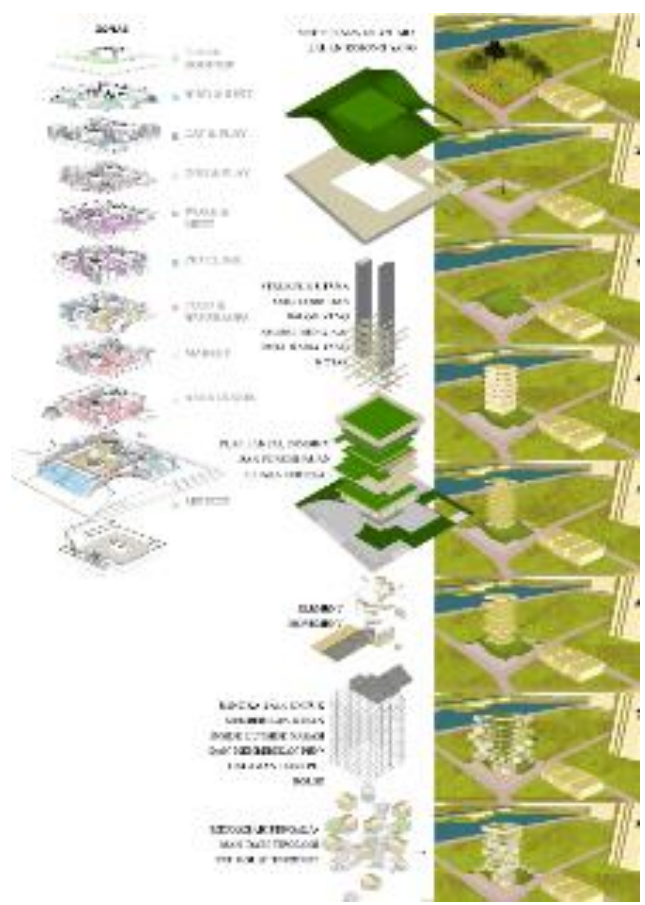

Gambar 8. Skema Desain dan Zonasi Sumber: Penulis, 2020 


\section{Konsep Struktural dan Material}

Bangunan ini terbentuk secara sederhana oleh core, plat lantai, rangka dan balok secara structural. Dan terbentuk secara material dari beton, besi dan segala jenis finishing lainnya. Sehingga dapat dijelaskan dalam gambar sebagai berikut.

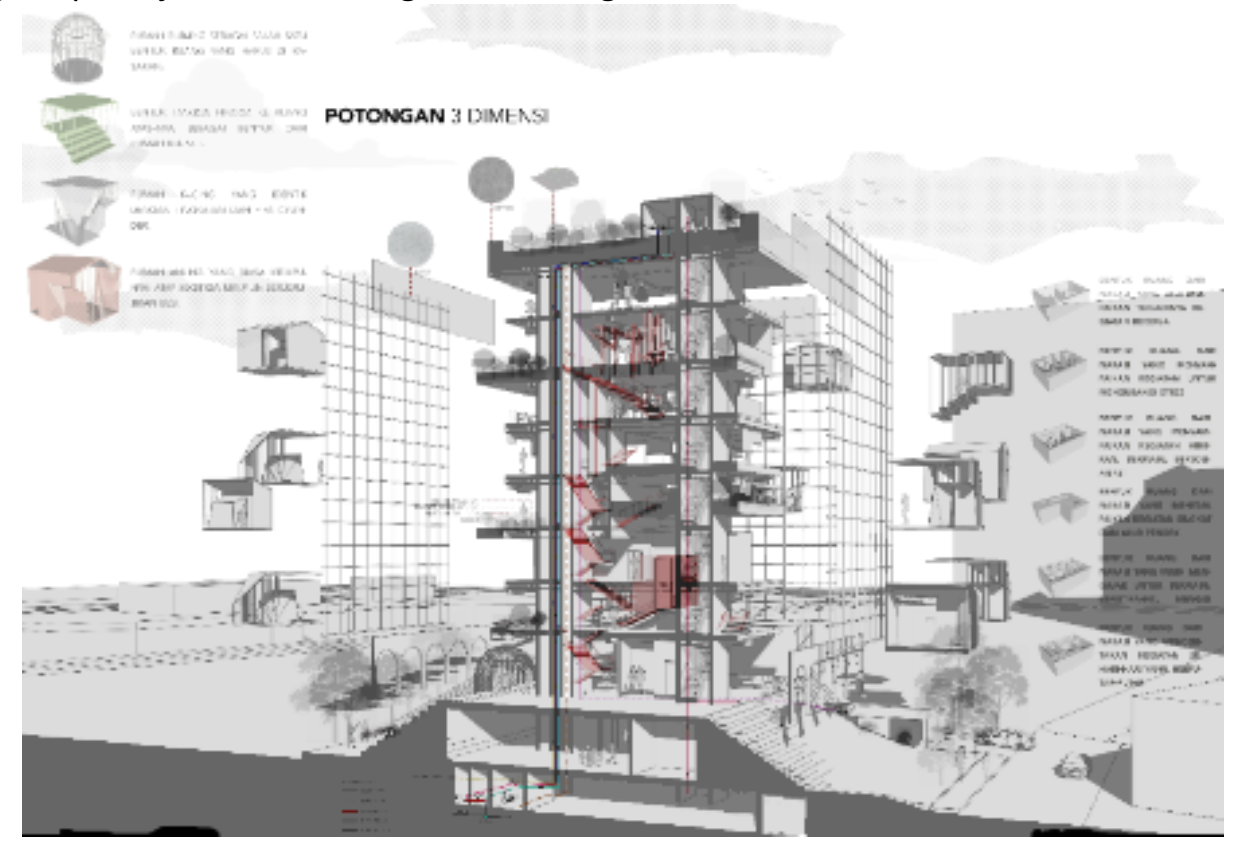

Gambar 9. Potongan Struktural dan Material

Sumber: Penulis, 2020.

\section{Konsep Third Place}

Dalam konsep untuk mendukung tempat ketiga di Kelurahan Setiabudi, terdapat berbagai aspek yang membuatnya menjadi sebuah tempat ketiga. Sehingga pada gambar dan tabel dibawah akan dijelaskan mengenai aspek-aspek bangunan pembentuk third place tersebut.

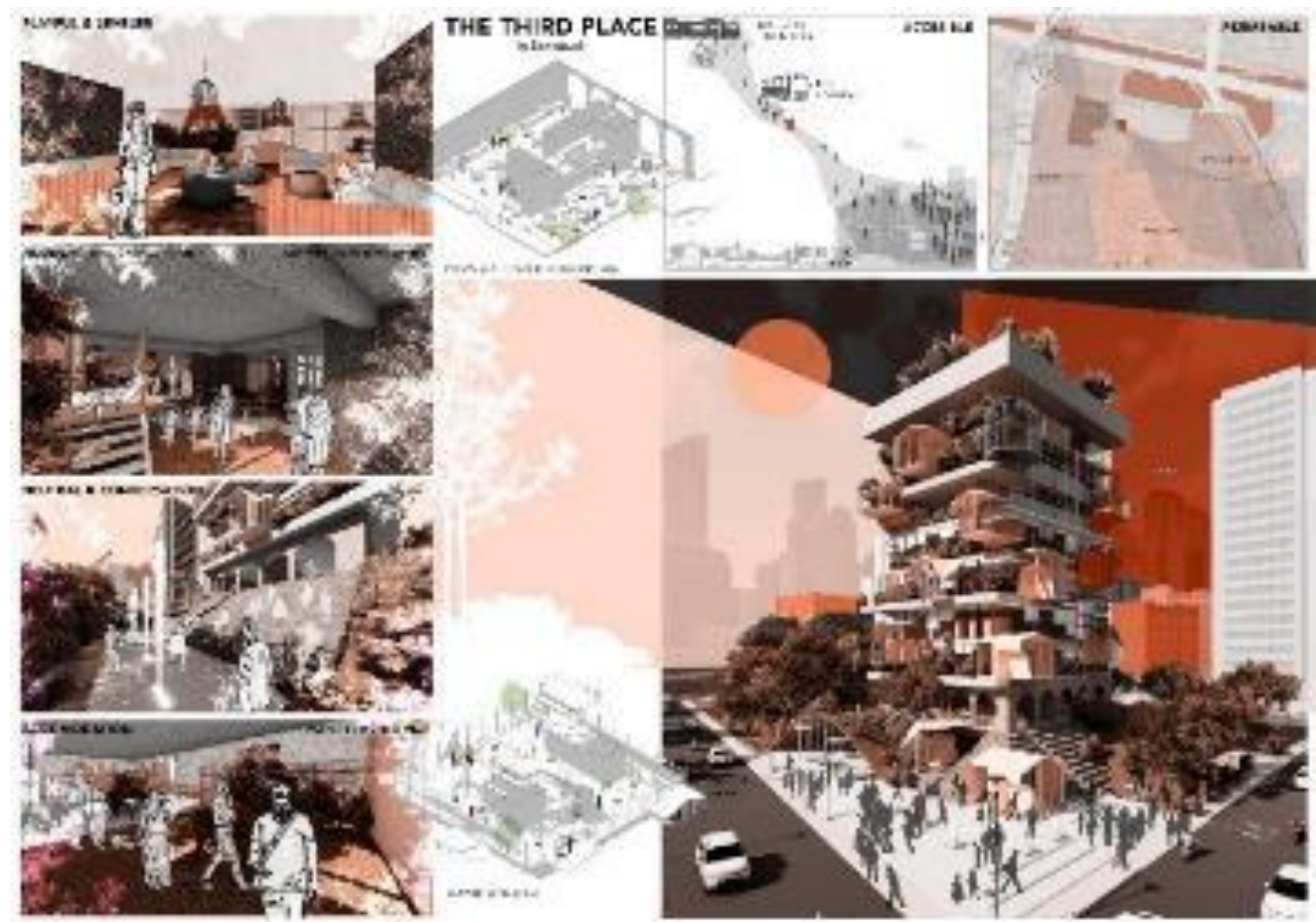

Gambar 10. Aspek Pembentuk Third Place Sumber: Penulis, 2020. 


\section{KESIMPULAN DAN SARAN}

\section{Kesimpulan}

Bangunan dengan tema When People Meet Pets tersebut akan menjadi bangunan yang berada di Kelurahan Setiabudi yang dapat mengakomodasi warganya menjadi salah satu third place dikawasan tersebut yang membuat warganya agar dapat saling bertemu, mengenal dan melepas stress dengan bermain bersama binatang serta manusia lainnya. Dengan suasana yang playful dan dapat mengakomodasi terjadinya interaksi sosial antara makhluk hidupnya, tempat ini akan membuat warga di kawasan tersebut dapat saling mengenal dan saling berinteraksi menjadi sebuah lingkungan yang baik.

Dengan konsep binatang yang ada pada bangunan, tempat ini diperuntukkan untuk melepas stres warganya dari kepenatan perkotaan yang sibuk dengan kegiatan sehari-hari. Sehingga manusia yang mengunjungi tempat ini dapat bermain bersama binatang untuk mendapat hormon endorfin yang dibutuhkan agar depresi manusia dapat berkurang. Bukan hanya keuntungan yang didapat oleh manusia dari bangunan tersebut, namun binatang-binatang yang terlantar juga dapat merasakan keuntungannya dengan dibutuhkannya mereka untuk dirawat dan diakomodasi oleh bangunan ini. Sehingga binatang dapat terurus dan dapat berinteraksi lagi secara bahagia dengan para manusia yang datang dan mengunjungi mereka. Dan landscape juga diperuntukkan untuk binatang liar yang ingin singgah untuk berteduh, mencari makanan maupun hanya sekedar bermain.

\section{Saran}

Dalam lingkungan perkotaan, kesibukan sehari-hari akan membuat manusia mudah depresi dan menyebabkan lingkungan dengan masyarakat yang tidak sehat. Maka dalam sebuah wilayah sangat dibutuhkan ruang ketiga tempat masyarakatnya dapat saling bertemu dan berkenalan untuk menghidupkan kembali suasana kota yang sehat.

\section{REFERENSI}

Antoniades, A. (1990). Poetics of Architecture: Theory of Design. New York: Van Nostrand Reinhold.

Fine, A. (2015). Handbook on Animal-Assited Therapy. California: Elsevier. Hertzberger, H. (1991). Lesson for Student in Architecture. Rotterdam: 010 Publisher. Lefebvre, H. (1991). The Production of Space. Oxford: Blackwell.

Oldenburg, R. (1991). The Great Good Place. New York: Marlowe \& Company.

Picon, A. (2015). Smart Cities: A Spatialized Intelligence. New Jersey: Wiley.

Richard, J. (2007). The Magazine of the American Society of Landscape Architecture. Washington,D.C.: ASLA.

Tshcumi, B. (1994). The Manhattan Transcripts. New York: The Academy Editions. 